\title{
DEVELOPMENT OF THE MUNICIPAL NOISE-ABSORBING SCREEN AND TEST SECTION CONSTRUCTION TECHNOLOGY
}

\author{
Ondřej Bret*, Petra ČížKová
}

\author{
Czech Technical University in Prague, Faculty of Civil Engineering \\ * corresponding author: ondrej.bret@fsv.cvut.cz
}

\begin{abstract}
The article presents the development and construction technology of the Municipal noise-absorbing screen (MNAS) - in Czech "Městská protihluková clona" (MPHC). The Municipal noise-absorbing screen is a new acoustical element developed in cooperation of the Department of Railway Structures, Faculty of Civil Engineering, CTU in Prague and the Montstav CZ s.r.o. Company. It is characterised by very small dimensions - its height is only ca 0.3 metre above the top of rail. The element serves to attenuate the noise induced by rail traffic arising at the wheel-rail contact. The Municipal noise-absorbing screen consists of individual, mutually interlocked units, placed one after another, made of bound recycled rubber. The article describes the major limiting conditions for the placement, shape and execution of the Municipal noise-absorbing screen. It also describes the construction of the test section situated on a tram track in Prague and sums up the experience obtained after the first year of operation.
\end{abstract}

KeYwords: Municipal Noise-absorbing Screen, noise pollution, tram traffic, tram cars, recycling, rubber granulate.

\section{INTRODUCTION}

The present-day requirements for admissible noise levels induced by both road and railway traffic in builtup residential areas have been increasingly growing. This issue is a subject of long-term discussions not only among professionals, but more and more frequently also within the public media space. The problem arising during the approval of reconstructed tram tracks in 2017 can serve as an example [1].

Traffic induced noise can be limited by active or passive noise reduction measures. Active noise reduction measures on the railway track in construction terms include, above all, a high-quality and well-maintained roadway, appropriate track construction design, rail fastening, application of rail absorbers and elimination of rail corrugation [2. Active noise reduction measures also include measures performed on vehicles. These are, above all, the wheel profile maintenance, bogie-mounted plates and other modifications of bogies. Even the application of suitable combinations of active measures, however, comes up against the ceiling of its potential and passive measures are necessary. Passive noise reduction measures include, for example, classic noise barriers, applied not only in rail transport, but also in road transport. The latest efforts are aimed at developing smaller-size elements, placed closed to the source of noise taking the form of various low noise-absorbing screens 3 .

Low noise-absorbing screens are elements or building units placed along tram tracks, railway tracks or other rail guided transport systems whose application results in the reduction of undesirable effects of noise arising during the passage of rail traffic [2]. Low noiseabsorbing screens are placed as close as possible to the structure gauge set by a technical standard. Thanks to their dimensions, they can be installed much closer to the source of noise as compared to classic noise barriers being thus able to attenuate the dominant noise arising at the wheel-rail contact (rolling noise) and the bogie noise [4, 5]. Depending on the material from which they are produced, they can have absorption or reflection properties.

\section{Municipal Noise-ABsorbing SCREEN}

The Municipal noise-absorbing screen (hereinafter also referred to as "MNAS") is a noise-absorbing element developed in cooperation of the Department of Railway Structures, Faculty of Civil Engineering, CTU in Prague and the Montstav CZ s.r.o. Company, engaged in the recycling and production of rubber elements. The operational verification runs in cooperation with the Prague Public Transit Company (PPTC).

MNAS serves for the attenuation of the noise induced by rail traffic, arising at the wheel-rail contact. The characteristic height of the screen is ca $30 \mathrm{~cm}$ above the top of rail (TR). The screen is placed in the immediate vicinity of the vehicle gauge and thus it effectively reduces the arising noise. The Municipal noise-absorbing screen is characterised by the material used - a composite based on recycled rubber granulate, bound by a polyurethane binder. The rubber granulate is a secondary raw material that can be used in railway construction in different applications [6], either in a bound [7, 8, or unbound state [9]. Unlike other similar elements, MNAS is easily demountable, which is a great advantage in the case of e.g. a nec- 
essary intervention of the integrated rescue system for which concrete noise barriers create a significant obstacle to a fast and smooth intervention [10].

The first-generation MNAS, which is the subject of this article, is presently being verified under operating conditions and its durability is monitored due to favourable thermal and technical properties of the rubber granulate [9] MNAS is presumed to resist winter conditions and degradation quite well [11. It is made up of units (segments) manufactured of bound recycled rubber with dimensions of $250 \times 600 \times 750$ $\mathrm{mm}$ (width $\mathrm{x}$ height $\mathrm{x}$ length), which are partially embedded below the ballast bed so that the height of the screen is ca $30 \mathrm{~cm}$ above the top of rail depending on the execution.

\section{Limiting CONDITIONS FOR MNAS PLACEMENT, SHAPE AND EXECUTION}

There were many limiting factors for the placement, shape and execution of the Municipal noise-absorbing screen emerging already in its design phase. The major limitations are the structure gauge, or the tramway vehicle gauge respectively. The design of the MNAS shape and placement was initially based on the vehicle gauge under ČSN 280318 - "Structure Gauges of Tramway Tracks" 12. According to this standard, the vehicle gauge width in a straight track section is $1300 \mathrm{~mm}$ from the rail axis. The reference vehicle considered in the above standard is a three-section tram of the KT8D5N type with a vehicle width of $2.5 \mathrm{~m}$ and a length of $30.3 \mathrm{~m}$. In Prague, this type is represented by a bi-directional tram of the KT8D5.RN2P type, which originated by the reconstruction of the KT8D5 tram [13, 14. Due to the fact that the vehicle gauge is very significantly extended in directional curves of small radii [12], the installation of MNAS is feasible mainly in straight sections and curves with radii from ca $200 \mathrm{~m}$. In straight sections and curves with large radii, it must be placed respecting the vehicle gauge pursuant to ČSN 280318 [12, or other limitations specific for the respective tram operation.

Other parameters for the MNAS placement on a test section within the Prague Public Transit Company (PPTC) network included potential passage of the PSP-01 bogie snow plough (Figure 1). The PSP01 snow plough was developed to meet the growing need for clearing snow from the rail space for the use of new low-floor vehicles. Due to the low-floor part, these vehicles have a greater width in the lower parts of the body casing than older (high-floor) trams, being, in some cases,equipped with other components in the part close to the top of rail which may cause problems in contact with water (snow). To allow smooth snow removal even in directional curves, the share of the PSP-01 bogie plough has a greater width than standard operated trams. Its total width is 2.6 $\mathrm{m}$ - i.e. 1.3 metres from the rail axis. Based on the need to preserve the possibility of the plough passage, this parameter must also be taken into account in

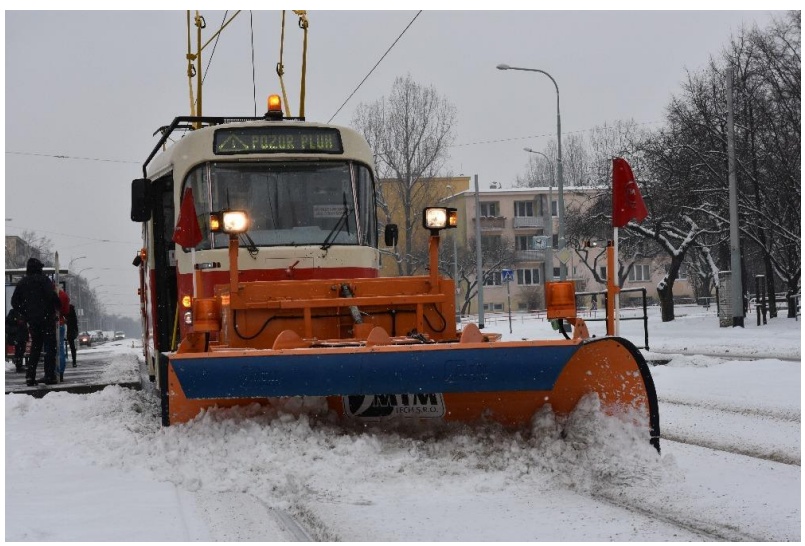

Figure 1. PSP-01 snow plough [15].

Prague and the screen must be placed with some reserve slightly further away from the rail axis than would be necessitated by the tram vehicle gauge.

Based on consultations with PPTC representatives over designs taking into account the above limitations, a question arose concerning a potential passenger escape exit from the tram in case of emergencies (accidents, vehicle failures, etc.,...) with respect to the screen placement. While older trams and their retrofits usually have four-section folding doors (opening in the inside direction) and modern trams are, as a rule, fitted with ejecting doors (opening in the outside direction, but only to a distance of several $\mathrm{cm}$ from the body casing), the possibility of opening tilting doors in the T6A5 type trams appeared as potentially problematic interfering with the screen placement. As seen in Figure 2, while opening the door the door leaves move along a circular trajectory getting to a distance of up to $360 \mathrm{~mm}$ from the body casing (1610 $\mathrm{mm}$ from the rail axis). Therefore, when placing MNAS to the right in the riding direction, the opening of the T6A5 tram door must be allowed, which can be achieved in two ways: 1) move the Municipal noise-absorbing screen further way from the rail axis, to a distance exceeding $1610 \mathrm{~mm}$ - which is a solution totally inappropriate it terms of the acoustic effectiveness of the MNAS element, or 2) select such a height of the screen above the top of rail allowing the tilting of the door - due to the height of the door at the maximum admissible wheel wear this level is at a height of $28 \mathrm{~cm}$ above $\mathrm{TR}$ - which is a solution feasible without problems. In placing the screen in the test section, this issue did not need to be solved as MNAS is placed to the left of the rail axis there, i.e. on the side without a door where it does not affect a potential evacuation of the passengers. It should be added that T6A5 trams are gradually discarded from traffic operation in Prague and replaced with new vehicles in which the door opening is solved by the above mentioned ejection of leaves, so that this limitation in placing MNAS on the door side will no longer apply in the future.

Based on the above conditions and limitations, a 


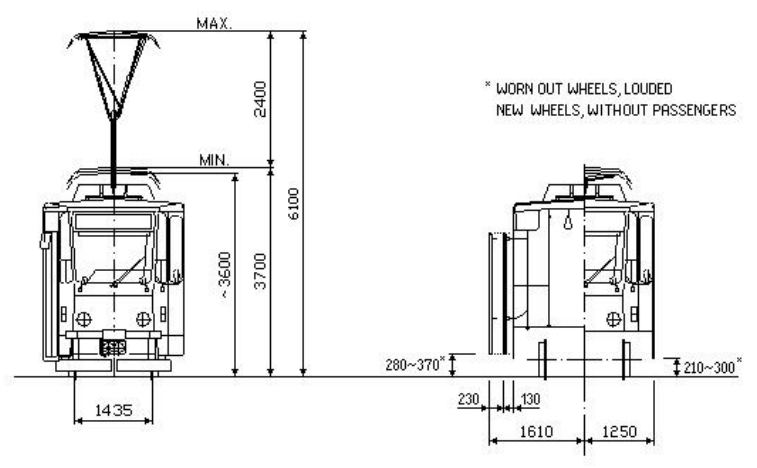

Figure 2. T6A5 tram - cross section, including the tilting door movement - plotting in a type drawing [16].

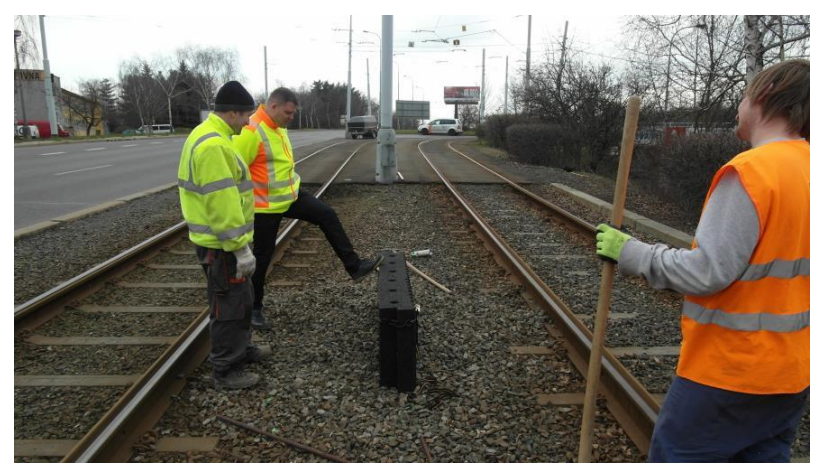

Figure 3. Mounting of MNAS prototypes - Vandal resistance test.

design of the MNAS placement in characteristic sections was developed and verified by the production and mounting of three prototype segments.

\subsection{VERIFICATION OF PROTOTYPES}

The trial placement of the prototypes was carried out on 23. 3. 2016 on a tram track close to the PPTC central workshops, in a section between Ústřední dílny Dopravního podniku - Na Homoli Stops. Both the team of the Department of Railway Structures FCE CTU and the representatives of PPTC, TT (Tram Track) Administration Section and DCT (Tram Traffic Route) Special Structures participated in the test. Apart from the construction / installation test, the verification included the compatibility and interaction of individual units and their vandal-resistance was tested - resistance to the displacement of individual segments of the screen (Figure 3). Based on local investigation, the final design of the placement and shape was developed and the connection of MNAS units was optimized.

\subsection{SELECTION OF A SECTION FOR TRIAL INSTALLATION}

The test section for the placement and verification of the acoustic properties of the Municipal noiseabsorbing screen (MNAS) was selected in cooperation with the Prague Public Transit Company (PPTC) again. Tracks with an open track structure were considered (even though MNAS can also be installed in a section with vegetation cover) of which the final choice fell on a tram track in Prague 4, direction Sídliště Modřany, the section Pobřežní cesta - Přístaviště in the Prague district of Braník.

The double track tram line in the respective section is led parallel to Modřanská Street, on a separate body with an open ballast bed. Grooved rails of the NT1 shape on TB93 concrete sleepers with W14 elastic baseplateless fastening are used there. The rail is executed as continuous welded rail.

The screen was installed on the centre-bound track, to the left of the riding direction (i.e. in the inter-track space). The MNAS position was selected with regard to the subsequent technical noise level measurement aimed at identifying the acoustic effectiveness of the designed noise reduction measure. The sound level meter microphone was located at a distance of 7.5 metres from the monitored track, on the side more distant from the road to eliminate the effect of passing car traffic. The characteristic section at the point of the noise-absorbing screen placement is shown in Figure 4. The selected distance of the screen face from the rail axis was $1420 \mathrm{~mm}$, and its height was $300 \mathrm{~mm}$ above the top of rail.

\subsection{TEST SECTION CONSTRUCTION}

The test section was established on 9. 4. 2016 in coordination with a one-day tram operation lockout in the Dvorce - Sídliště Modřany section, planned for the overhaul and maintenance of traction wires. In the morning before the lockout, accurate measurement and marking of the site for the placement and installation of the Municipal noise-absorbing screen plus other preparatory works had been performed. Immediately after the start of the lockout, the MHS two-way excavator made a groove in the ballast bed for the installation of MNAS units (Figure 5). Successive work was done manually, without machinery. The site construction camp and vehicle parking were established near Pobřežní cesta Stop, by the exit of the link road from Barrandov Bridge onto Modřanská Street, ca $200 \mathrm{~m}$ from the established test section. From there, the MNAS segments, tools and other material were transported by a track trolley.

The width of the previously excavated groove necessary for mounting the MNAS segments and the depth related to the top of rail (TR) were checked and further extended as necessary. Before the installation of units, the gravel bearing surface was compacted with a manual petrol powered vibrating plate (Figure 6).

Individual MNAS units were gradually mounted onto the compacted surface, proceeding step by step from the start of the section towards Přístaviště Stop. The position of installed units in relation to the rail was continuously checked - their distance from the rail axis (structure gauge) and their height above TR (Figure 7). Mounted units were gradually backfilled 


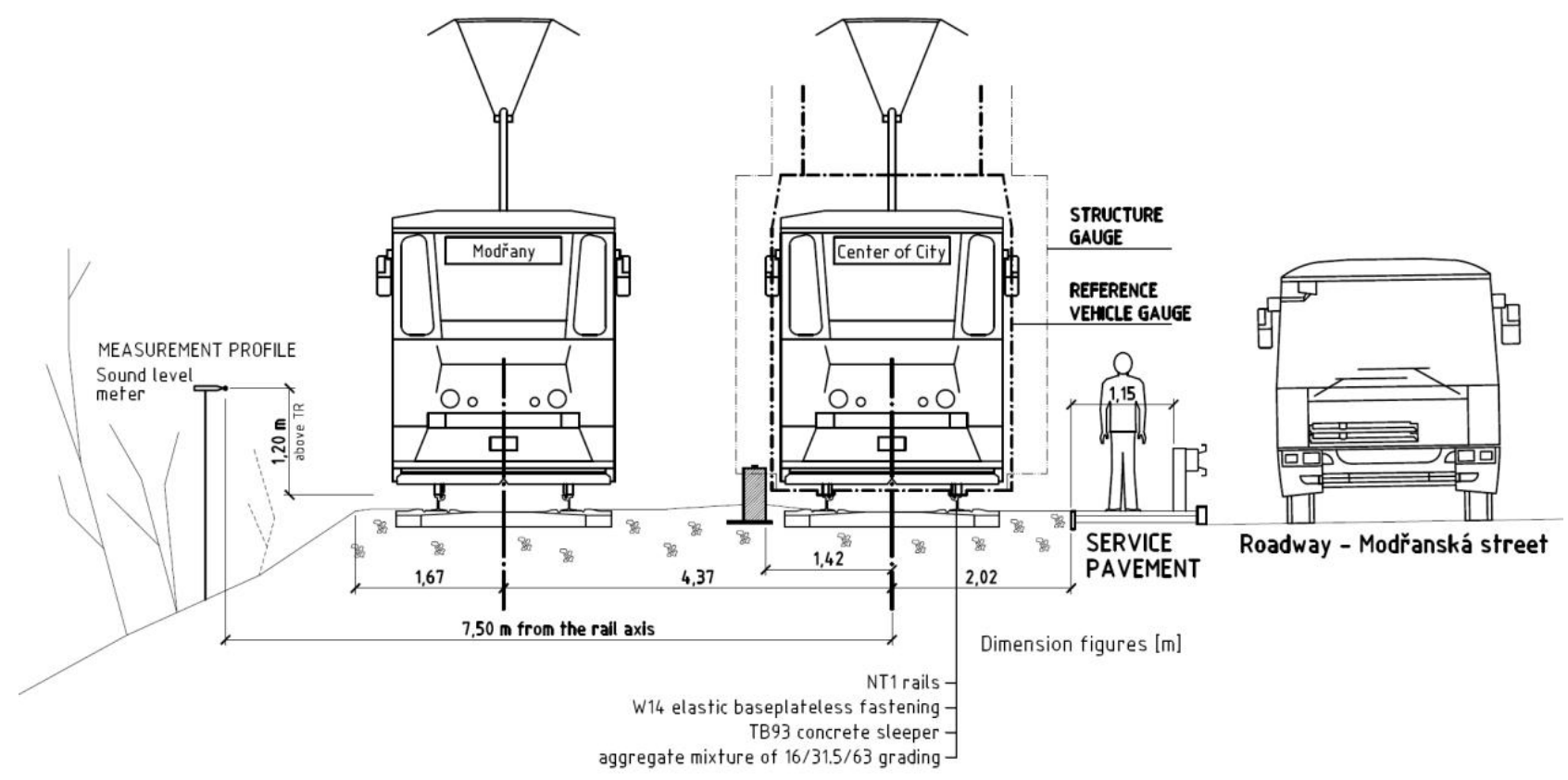

Figure 4. Characteristic section at the point of the noise-absorbing screen placement.

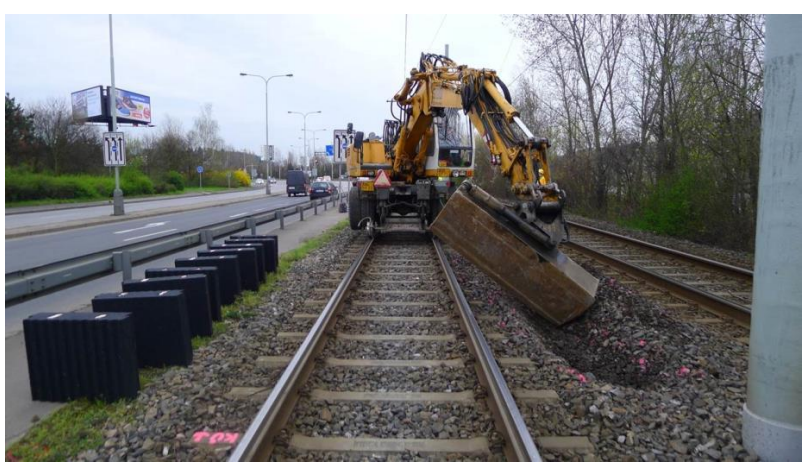

Figure 5. Groove excavation for mounting MNAS using the MHS two-way excavator.

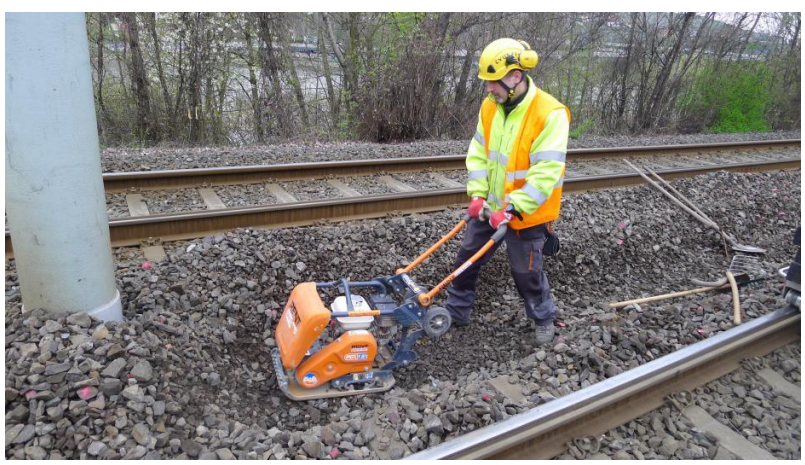

FiguRE 6. Compaction of groove surface prior to the screen placement.

with gravel, which was compacted, both manually and using machinery. Individual units were mutually interlocked by wooden laths placed on the upper side of the screen (Figure 8) - this ensures the interaction of the whole screen (necessary e.g. to resist vandalism) and also secures its permanent position.

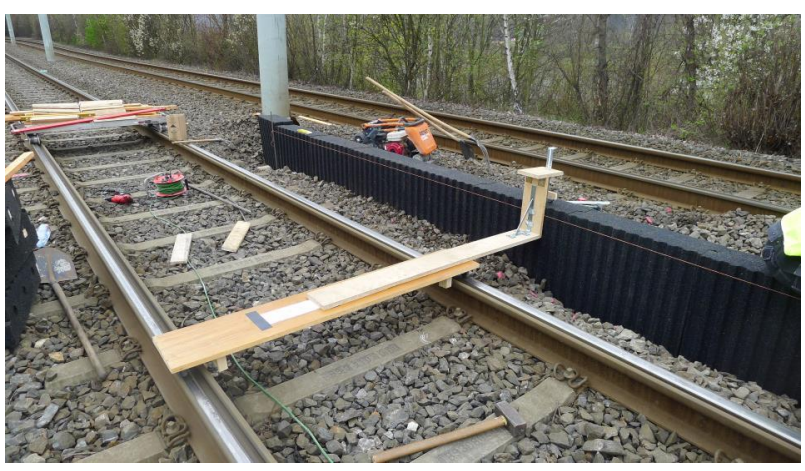

Figure 7. Checking the screen distance and height from the rail axis and TR.

An atypically chamfered unit preventing the crash of tram units into the front of the screen in case of emergency (e.g. displacement of screen units due to vandalism) was mounted onto the front of the Municipal noise-absorbing screen in the riding direction (i.e. in the direction from Pobřežní cesta Stop) (Figures gp . After the final check of the position of all units, final modifications of the ballast bed profile were made and the gravel around the installed MNAS was compacted with a manual petrol powered vibrating plate.

A total of 32 MNAS units were installed, the test section being 24 metres in length.

\subsection{SCREEN MODIFICATION}

Following noise measurement monitoring the state after the MNAS construction, the screen was modified to improve the acoustic effectiveness of the noise reduction measure used. This modification consisted in adding boards of recycled rubber, $25 \mathrm{~mm}$ in thickness, to the upper screen wall, which created an overlap, 


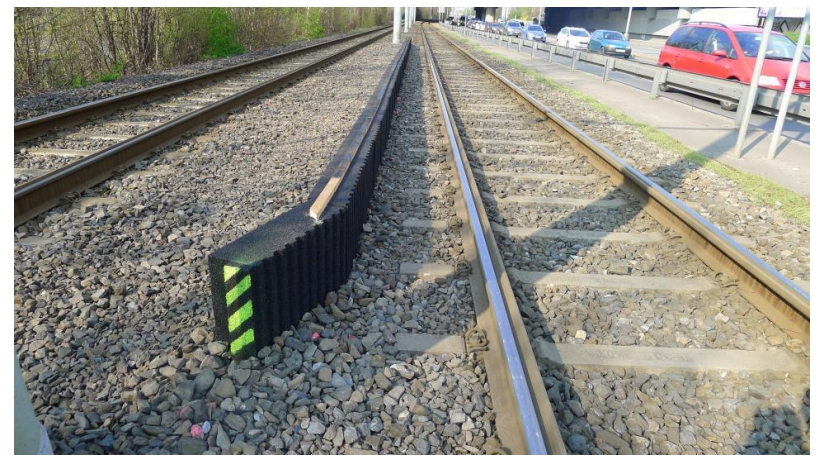

FiguRE 8. MNAS seen from the start of the section chamfered first unit is evident in the front.

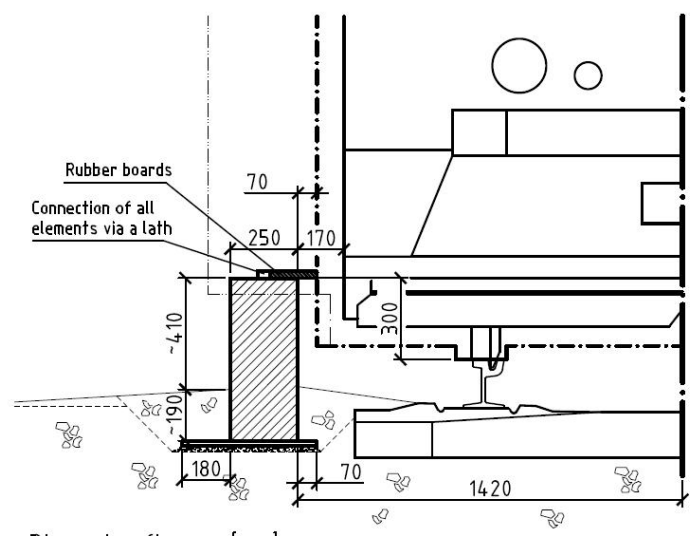

Dimension figures [mm]

Figure 9. Detail of modified MNAS execution.

$70 \mathrm{~mm}$ in length, at the screen face to further reduce the arising noise. Thanks to the board overlap, the screen face was shifted towards the track, from the original distance of $1.42 \mathrm{~m}$ from the rail axis to 1.35 $\mathrm{m}$ after the modification. The modification is evident from Figure 9 .

The screen was modified under traffic operation on 26.4.2016. The modification was performed using boards of recycled rubber, pre-cut to the necessary dimensions. The boards were fastened to individual MNAS segments with $0.5 \mathrm{~m}$ spacing by means of dowels into polystyrene - this solution proved to be the most convenient based on tests. After the installation of additional boards providing the overlap of the screen towards the track, the measurement of noise was carried out to verify the effectiveness of modified MNAS. The solved section with completed MNAS, including the modification, is presented in Figure 10

\section{Conclusion}

The designed and implemented noise reduction measure proved to be an effective alternative for the attenuation of noise induced by tram traffic. The measured data served to establish the average energy value for all measured passages of tram units. The resulting reduction due to the Municipal noise-absorbing screen (MNAS) application after its modification identified

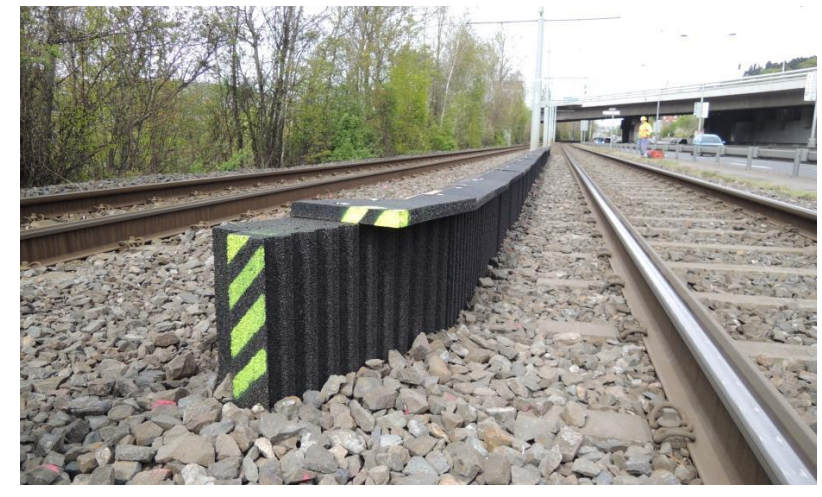

Figure 10. Municipal Noise-absorbing Screen after modification.

was $3.9 \mathrm{~dB}$. Some types of trams (in relation to the body casing shape at the bogie level) even reached higher noise reduction levels. More detailed information about the MNAS effectiveness will be published in the professional peer-reviewed journal, Akustika, in autumn 2017 (www.akustikad.com).

The test section is currently subjected to continuous monitoring and different parameters are surveyed on it on a long-term basis. After the first year of operation and the first winter season, the Municipal noise-absorbing screen does not show any signs of mechanical damage, degradation or other defects.

In 2016, the Industrial Property Protection Agency awarded the Municipal noise-absorbing screen the Industrial and Utility Model certificate.

In the following phases of research and development, further monitoring of the first-generation MNAS test section, described in this article, and the construction and verification of the second-generation MNAS test section or sections is presumed where structural improvements, designed on the basis of experience obtained from the construction and monitoring of the first-generation test section, will be applied.

\section{REFERENCES}

[1] K. Frouzová. Praha musí řešit hlučné tramvaje na opravených tratích. Hrozí omezení nebo zrušení desítky spojů / Prague must Solve Noisy Trams on Repaired Tracks. There is a Threat of Limitation or Cancellation of Ten Lines, In: www.ihned.cz: Hospodářské noviny [online]. [cit. 2017-03-10]

http://domaci.ihned.cz/c1-65569370-praha-musi-resithlucne-tramvaje-na-opravenych-tratich-hrozi-omezeninebo-zruseni-desitky-spoju.

[2] P. Č́žková. The Acoustic Effectiveness of Low Height Noise Barrier. In: KROPP, W, ed. Proceedings of the 45th International Congress on Noise Control Engineering. INTER-NOISE 2016, Hamburg, 2016-08-21/2016-08-24. Berlin: German Acoustical Society (DEGA), 2016. ISBN 978-3-939296-11-9.

[3] J. Smutný, L. Pazdera, V. Tomandl. Assessment of the Effectiveness od Low Noise Barrier BRENS BARRIER in Tetčice village. In: EISEREICH, J.E., ed. Rychlost $s$ tichostí. Rychlost s tichostí 2015, Plzeř. Praha:

Powerprint, 2015. ISBN 978-80-87994-28-3. 
[4] P. Č́žzová, L. Lomoz. The effectiveness of a low height noise barrier. In: 14th GeoConference on ECOLOGY, ECONOMICS, EDUCATION AND LEGISLATION. 14th International Multidisciplinary Scientific Geoconference SGEM 2014, Albena, 2014-06-17/2014-06-26. Sofia: STEF92 Technology Ltd., 2014. ISSN 1314-2704, ISBN 978-619-7105-18-6, DOI 10.5593/SGEM2014/B52/S20.094.

[5] P. Č́žzová, L. Lomoz. Comparison of efficacy of low and hight acoustic screens. Akustika, 2014. ISSN 1801-9064.

[6] M. Lidmila. Nové perspektivy využití recyklovaných materiálů v železničním stavitelství / New Perspectives of Using Recycled Materials in Railway Construction, In: Udržitelná výstavba. ČVUT v Praze, 2011. ISBN 978-80-01-04961-7.

[7] L. Horníček, H. Krejčíková, M. Lidmila, et al. Antivibrační rohože $v$ železničním stavitelství v $\check{C} R /$ Antivibration Mats in Railway Construction in the Czech Republic. České vysoké učení technické v Praze, Fakulta stavební, 2011. ISBN 978-80-01-04963-1.

[8] J. Makuch. Maty wibroizolacyjne we wrocławskich torach tramvajowych. In: XIV Konferencja Naukowo-Techniczna "Drogi Kolejowe 2007" [online], 2007. [cit. 2017-03-7] http://www.zits.pwr.wroc.pl/makuch/art38.pdf.

[9] M. Lidmila, V. Lojda, O. Bret. Laboratory models of a railway track with the subgrade layer based on rubber granulate In: Advances and Trends in Engineering Sciences and Technologies II: Proceedings of the 2nd
International Conference on Engineering Sciences and Technologies, 29 June - 1 July 2016, High Tatras Mountains, Tatranské Matliare, Slovak Republic. Boca Raton: CRC Press, 2016. ISBN 9781138032248.

[10] Protihlukové stěny hluku nezabrání a jsou bezpečnostní komplikací / Noise-absorbing Walls do not Prevent Noise being an Obstacle to Safety, želpage [online]. [cit. 2017-03-10] http://www.zelpage.cz/zpravy/8188?lang $=$ cs

[11] O. Bret. Determination of Rubber Granulate Frost Protection. In: Juniorstav 2017, 19. odborná konference doktorského studia. Brno: Vysoké učení technické v Brně, Fakulta stavební, 2017. ISBN 978-80-214-5473-6.

[12] ČSN 28 0318. Průjezdné průrezy tramvajových tratí a obrysy pro vozidla provozovaná na tramvajových dráhách / Structure Gauges and Vehicle Gauges for Vehicles Operated on Tram Tracks. Praha: Český normalizační institut, 2015.

[13] KATALOGOVÝ LIST TRAMVAJOVÉHO VOZU KT8D5. SKD TRADE, a.s. / CATALOGUE SHEET OF T6A5. TRAM CAR OF SKD TRADE a.s. [online]. [cit. 2017-03-18] http://www.skd.cz/tramvaje/KT8D5.htm.

[14] R. Mara. Pražské tramvaje. Praha: Pavel Malkus Dopravní vydavatelství, 9/2012. ISBN 978-80-87047-28-6.

[15] Archives of the Prague Public Transit Company.

[16] KATALOGOVÝ LIST TRAMVAJOVÉHO VOZU T6A5. SKD TRADE a.s. / CATALOGUE SHEET OF T6A5. TRAM CAR OF SKD TRADE a.s. [online]. [cit. 2017-03-18] http://www.skd.cz/tramvaje/T6A5.htm. 